\title{
PENGARUH EFEKTIVITAS PENGENDALIAN INTERNAL, KESESUAIN KOMPENSASI, MORALITAS MANAJEMEN, KETAATAN ATURAN AKUNTANSI, DAN ASIMETRI INFORMASI TERHADAP KECENDERUNGAN KECURANGAN AKUNTANSI
}

\section{THE INFLUENCES OF EFFECTIVENESS OF INTERNAL CONTROL, COMPATIBILITY OF COMPENSATION, MORALITY OF MANAGEMENT, OBEDIENCE OF ACCOUNTING RULE, AND ASYMMENTRY INFORMATION ON THE TENDENCY OF ACCOUNTING FRAUD.}

\author{
Irwansyah $^{1}$ ), Bambang Syufriadi²)
}

Universitas Bengkulu, Jl. WR. Supratman,Kandang Limun, Muara Bangkahulu, Bengkulu onesyah2000@yahoo.com ${ }^{I}$ ), bambangsyufriadi@gmail.com ${ }^{2}$ )

\begin{abstract}
This study aims to determine the effect of internal control effectiveness, suitability of compensation, the morality of management, the observance of accounting rules, and information asymmetry to the tendency of accounting fraud (a survey of the company's distributor in the city of Bengkulu). The data used in this research is primary data, which is obtained by spreading the questionnaire. The number of samples used in this study is 50 samples. Data analysis techniques using the help of IBM SPSS 16.0. The results showed that the effectiveness of the internal control and the morality of management negatively affect the tendency of accounting fraud. While information asymmetry has a positive effect on the tendency of accounting fraud. To the suitability of the compensation and the observance of accounting rules does not negatively affect the tendency of accounting fraud.
\end{abstract}

Key words: Influence, Compensation, Management, Rules, Asymmetry, Accounting

\section{ABSTRAK}

Penelitian ini bertujuan untuk mengetahui pengaruh efektivitas pengendalian internal, kesesuaian kompensasi, moralitas manajemen, ketaatan aturan akuntansi, dan asimetri informasi terhadap kecenderungan kecurangan akuntansi (survei pada perusahaan distributor di Kota Bengkulu). Data yang digunakan dalam penelitian ini ialah data primer, yang diperoleh dengan menyebarkan kuesioner. Jumlah sampel yang digunakan dalam penelitian ini ialah 50 sampel. Teknik analisis data menggunakan bantuan IBM SPSS 16.0. Hasil penelitian menunjukkan bahwa efektivitas pengendalian internal dan moralitas manajemen berpengaruh negatif terhadap kecenderungan kecurangan akuntansi. Sedangkan asimetri informasi berpengaruh positif terhadap kecenderungan kecurangan akuntansi. Untuk kesesuaian kompensasi dan ketaatan aturan akuntansi tidak berpengaruh negatif terhadap kecenderungan kecurangan akuntansi.

Kata Kunci: Pengaruh, Kompensasi, Manajemen, Aturan, , Asimetri, Akuntansi.

\section{PENDAHULUAN}

Fenomena kecurangan merupakan salah satu isu yang sangat mengkhawatirkan saat ini. Permasalahan kecurangan ini selalu menarik perhatian media dan menjadi salah satu yang menonjol baik di dalam negeri maupun di luar negeri. Dalam dunia bisnis seringkali terjadi kecurangan-kecurangan atau tindakan menyimpang dari prosedur yang seharusnya. Kecurangan banyak terjadi diberbagai bidang, salah satunya dalam bidang akuntansi. Kecurangan yang sering terjadi dibidang akuntansi disuatu perusahaan seperti memanipulasi 
atau melakukan suatu penipuan dalam hal melaporkan data terkait keuangan ataupun nonkeuangan.

Kencenderungan kecurangan akuntansi dapat disebabkan oleh faktor-faktor tertentu, dan kenderungan kecurangan akuntansi dapat dijelaskan menggunakan beberapa teori seperti Fraud Diamond Theory dan teori atribusi. Teori atribusi yang dikemukakan oleh Fritz Heider menjelaskan tentang penyebab seseorang melakukan perilaku tertentu (Rahmawati, 2012). Begitu juga dengan teori Fraud Diamond yang dikemukakan pertama kali oleh Wolfe dan Hermanson (2004) menjelaskan faktor-faktor yang melatarbelakangi kecenderungan kecurangan seseorang (Theodorus, 2010). Kedua teori ini dapat digunakan untuk menjelaskan faktor-faktor yang mempengaruhi kecenderungan kecurangan akuntansi. Ada beberapa hal yang membuat terjadinya kecenderungan untuk melakukan suatu kecurangan seperti kurang efektifnya pengendalian internal, tidak sesuainya kompensasi yang diberikan oleh perusahaan, kurang taatnya karyawan dalam hal mengikuti aturan yang telah dibuat, kurang asimetri informasi yang telah diberikan perusahaan, dan moralitas manajeman yang kurang dalam memperlakukan karyawan.

\section{Rumusan Masalah}

Berdasarkan latar belakang di atas, maka permasalahan pokok penelitian ini adalah:

1. Apakah efektivitas pengendalian internal berpengaruh negatif terhadap kecenderungan kecurangan akuntansi ?

2. Apakah kesesuain kompensasi berpengaruh negatif terhadap kecenderungan kecurangan akuntansi ?

3. Apakah moralitas manajemen berpengaruh negatif terhadap kecenderungan kecurangan akuntansi ?

4. Apakah ketaatan aturan akuntansi berpengaruh negatif terhadap kecenderungan kecurangan akuntansi ?

5. Apakah asimetri informasi berpengaruh positif terhadap kecenderungan kecurangan akuntansi?

\section{KERANGKA TEORITIS DAN HIPOTESIS}

\section{Fraud Diamond Theory}

Teori Fraud Diamond merupakan teori yang menjadi dasar atau latar belakang untuk seseorang dalam melakukan kecurangan yang disajikan pertama kali oleh Wolfe dan Hermanson (2004). Dalam Fraud Diamond menambahkan komponen Capability/kemampuan setelah 3 komponen yang terdapat dalam Fraud triangle Theory yang dikemukakan oleh Cressey (1973), yaitu rationalization, pressure, dan opportunity.

\section{Teori Atribusi}

Teori atribusi yang dikembangkan oleh Kelley (1967), kemudian Green serta Mitchell (1979) berpandangan bahwa perilaku kepemimpinan disebabkan oleh atribut penyebab, dimana semua pandangan, model, dan teori tidak terlepas dari perilaku orang dalam organisasi yaitu perilaku pimpinan dan perilaku bawahan. Jadi kepemimpinan tidak terlepas dari cara berpikir, berperasaan, bertindak, bersikap, dan berperilaku termasuk tindakan tidak etis maupun kecurangan yang terjadi dalam sebuah organisasi (Rahmawati, 2012). Faktor-faktor seperti kesesuaian kompensasi, moralitas individu, asimetri informasi, dan efektivitas pegendalian internal merupakan beberapa faktor yang menjadi penyebab terjadinya kecurangan tersebut. 


\section{Pengendalian Internal}

Pengendalian internal sebagai suatu proses yang dijalankan oleh dewan komisaris, manajemen, dan personel lain entitas yang didesain untuk memberikan keyakinan memadai tentang pencapaian tiga golongan meliputi keandalan pelaporan keuangan, efektivitas dan efisiensi operasi, serta kepatuhan terhadap hukum dan peraturan yang berlaku. Tercapainya pengendalian internal dalam suatu perusahaan dapat meminimalisir kerugian atau pemborosan pengelolaan sumber daya perusahaan. Pengendalian internal juga menyediakan informasi tentang bagaimana menilai kinerja perusahaan dan manajemen sebagai pedoman dalam perencanaan selanjutnya.

\section{Kecurangan Akuntansi}

Yuli (2013) menyatakan Kecurangan merupakan suatu istilah umum, dan mencakup segala macam cara yang dapat digunakan dengan kelihaian tertentu, yang dipilih oleh seorang individu, untuk mendapatkan keuntungan dari pihak lain dengan melakukan representasi yang salah. Tidak ada aturan yang baku dan tetap yang bisa dikeluarkan sebagai proposisi umum dalam mendefinisikan kecurangan, termasuk kejahatan, tipu muslihat, ataupun cara-cara yang licik dan tidak wajar yang digunakan untuk melakukan penipuan. Batasan satu-satunya dalam mendefinisikan kecurangan adalah hal-hal yang membatasi ketidakjujuran manusia.

\section{Ketaatan Aturan Akuntansi}

Ardiana Peni Rahmawati (2012: 19) menyatakan bahwa standar akuntansi disusun untuk menjadi dasar penyusunan laporan keuangan. Standar akuntansi tersebut terdiri atas pedoman-pedoman yang digunakan untuk mengukur dan menyajikan laporan keuangan. Dengan demikian ketaatan aturan akuntansi adalah kepatuhan dalam menaati pedomanpedoman yang digunakan untuk menyusun dan menyajikan laporan keuangan. Jika laporan keuangan tidak disusun berdasarkan standar akuntansi yang berlaku, maka akan memberikan kesempatan terjadinya kecurangan akuntansi yang akan merugikan pihak pengguna laporan keuangan.

\section{Kesesuaian Kompensasi}

Kompensasi merupakan balas jasa yang diberikan oleh organisasi kepada karyawan, yang dapat bersifat finansial maupun non finansial pada periode yang tetap. Sistem kompensasi yang baik akan mampu memberikan kepuasan bagi karyawan dan memungkinkan perusahaan memperoleh, memperkerjakan, dan mempertahankan karyawan. Bagi organisasi, kompensasi memiliki arti penting, karena kompensasi mencerminkan upaya organisasi dalam mempertahankan dan meningkatkan kesejahteraan karyawannya. Beberapa pengalaman menunjukkan bahwa kompensasi yang tidak memadai dapat menurunkan prestasi kerja, motivasi kerja, dan kepuasan kerja karyawan, bahkan dapat menyebabkan karyawan yang potensial keluar dari perusahaan. Kompensasi merupakan alat pengikat perusahaan terhadap karyawannya, faktor penarik bagi calon karyawan dan faktor pendorong seseorang menjadi karyawan.

\section{Asimetri Informasi}

Indriani (2013) dalam penelitiannya mengatakan bahwa perkembangan informasi berlangsung sangat cepat dalam era globalisasi, begitu juga kondisi lingkungan ekonomi yang 
berhubungan erat dengan bisnis yang terus mengalami perubahan membutuhkan infromasi antara lain adalah informasi yang diperoleh dari laporan keuangan. Laporan keuangan merupakan sarana pengkomunikasian informasi keuangan kepada pihak-pihak yang berkepentingan. Laporan keuangan memiliki kelemahan tertentu, sekalipun pembuatan laporan keuangan diatur oleh suatu standar yang telah ditetapkan, namun perlu disadari bahwa laporan keuangan mengandung banyak asumsi, penilaian, serta pemilihan metode perhitungan yang dapat digunakan oleh pembuatnya. Adanya pemilihan kebijakan akuntansi dalamstandar yang dapat digunakan tersebut membuat manajemen memiliki cukup keleluasaan untuk memanipulasi laporan keuangan tersebut.

\section{Moralitas Manajemen}

Perbuatan, sikap ataupun tingkah laku yang dilakukan oleh manusia dalam kehidupan sehari-hari sangatlah erat kaitannya dengan orang lain. Secara umum moralitas adalah hal mendasar dalam penilaian atas setiap tindakan yang diambil oleh manusia. Tiara Delfi (2014) menjelaskan bahwa moralitas berkaitan dengan orang lain bukan hanya mengenai kepentingan pribadi. Serta moralitas merupakan pemikiran yang objektif dan rasional. Selain itu moralitas merupakan hukum yang universal yang penting.

\section{Pengembangan Hipotesis}

\section{Efektivitas Pengendalian Internal dan Kecenderungan Kecurangan Akuntansi.}

Adanya peluang menjadi salah satu penyebab terjadinya kecurangan akuntansi. Pengendalian Internal yang efektif dalam suatu instansi merupakan hal yang penting. Pengendalian internal yang efektif dapat mengurangi peluang atau kesempatan yang dimiliki oleh karyawan untuk melakukan kecurangan akuntansi. Semakin buruk pengendalian internal yang dimiliki oleh instansi, maka semakin besar pula peluang yang dapat dimanfaatkan untuk melakukan kecurangan akuntansi. Dengan demikian, sebuah instansi harus memiliki pengendalian internal yang efektif agar segala kebijakan dan prosedur yang ditetapkan oleh instansi dipatuhi oleh seluruh karyawan.

Ada beberapa penelitian lain yang menyatakan hal yang sama seperti penelitian Kusumastuti (2012), Rahmawati (2012) dan Shintadevi (2015). Dari penelitian diatas menunjukkan bahwa efektivitas pengendalian internal berpengaruh negatif terhadap kecenderungan kecurangan akuntansi. Berdasarkan teori tersebut dan penelitian terdahulu yang memiliki perbedaan, maka dapat disimpulkan hipotesis sebagai berikut:

H1 : Efektivitas Pengendalian Internal Berpengaruh Negatif Terhadap Kecenderungan

Kecurangan Akuntansi pada Karyawan Perusahaan Distributor Di Kota Bengkulu.

\section{Kesesuaian Kompensasi Dan Kecenderungan Kecurangan Akuntansi.}

Seseorang cenderung akan melakukan suatu hal untuk mendapatkan kompensasi. Jika kompensasi diberikan kepada manajemen, maka manajemen cenderung bertindak sesuai keinginan perusahaan dan menghindari tindakan menyimpang agar tetap mendapatkan kompensasi. Kompensasi merupakan hal yang berpengaruh terhadap tindakan maupun perilaku seseorang dalam organisasi. Seseorang cenderung berperilaku tidak etis untuk memaksimalkan keuntungan pribadinya. Kompensasi tersebut bertujuan agar manajemen dapat bertindak sesuai keinginan pemilik perusahaan dan tidak melakukan tindakan menyimpang seperti adanya perilaku tidak etis. Tindakan menyimpang diharapkan dapat berkurang dengan adanya sistem kompensasi yang diberikan. 
Penelitian ini berpendapat bahwa pemberian kompensasi yang sesuai akan menurunkan perilaku tidak etis manajemen perusahaan Ada beberapa penelitian lain yang menyatakan hal yang sama seperti penelitian Kusumastuti (2012), Rahmawati (2012), dan Shintadevi (2015). Dari penelitian diatas menunjukkan bahwa kesesuaian kompensasi berpengaruh negatif terhadap kecenderungan kecurangan akuntansi. Berdasarkan teori tersebut dan penelitian terdahulu yang memiliki perbedaan, maka dapat disimpulkan hipotesis sebagai berikut:

H2 : Kesesuaian Kompensasi Berpengaruh Negatif Terhadap Kecenderungan Kecurangan Akuntansi pada Karyawan Perusahaan Distributor Di Kota Bengkulu.

\section{Moralitas Manajemen Dan Kecenderungan Kecurangan Akuntansi}

Agency Theory menyebutkan bahwa adanya perilaku dari manajer/agen yang bertindak hanya untuk menguntungkan dirinya sendiri dengan mengorbankan kepentingan pihak lain/pemilik. Hal ini tidak sesuai dengan kematangan moral manajemen yang menjadi indikasi pembuatan keputusan.

Berdasarkan teori tersebut dan penelitian terdahulu yang memiliki perbedaan, maka dapat disimpulkan hipotesis sebagai berikut:

H3 : Moralitas Manajemen Berpengaruh Negatif Terhadap Kecenderungan Kecurangan Akuntansi pada Karyawan Perusahaan Distributor Di Kota Bengkulu.

\section{Asimetri Informasi Dan Kecenderungan Kecurangan Akuntansi.}

Asimetri informasi ini membuat manajemen memanfaatkan ketidakselarasan informasi untuk keuntungan mereka serta sekaligus merugikan pihak luar perusahaan, seperti membiaskan informasi yang terkait dengan investor dan teori tersebut didukung dengan penelitian Mustikasari (2013) bahwa asimetri informasi berpengaruh positif terhadap fraud, artinya jika terjadi asimetri informasi dapat menyebabkan terjadinya fraud. Semakin di dukung dengan penelitian yang dilakukan Najahningrum (2013) menunjukkan bahwa asimetri infromasi berpengaruh positif terhadap fraud artinya semakin tinggi asimetri.

Berdasarkan teori tersebut dan penelitian terdahulu yang memiliki perbedaan, maka dapat disimpulkan hipotesis sebagai berikut:

H4 : Asimetri Informasi Berpengaruh Positif Terhadap Kecenderungan Kecurangan Akuntansi pada Karyawan Perusahaan Distributor Di Kota Bengkulu.

\section{Ketaatan Aturan Akuntansi Dan Kecenderungan Kecurangan Akuntansi.}

Rahmawati (2012: 19) menyatakan bahwa standar akuntansi disusun untuk menjadi dasar penyusunan laporan keuangan. Standar akuntansi tersebut terdiri atas pedoman-pedoman yang digunakan untuk mengukur dan menyajikan laporan keuangan. Perusahaan yang menaati segala pedoman dalam mengukur dan menyajikan laporan keuangan sesuai dengan standar akuntansi yang berlaku akan memperkecil celah karyawan dalam melakukan kecurangan akuntansi. Sebaliknya, perusahaan yang tidak menaati standar akuntansi dalam mengukur dan menyajikan laporan keuangan, peluang karayawan untuk melakukan kecurangan akuntansi akan semakin tinggi.

Berdasarkan teori tersebut dan penelitian terdahulu yang memiliki perbedaan, maka dapat disimpulkan hipotesis sebagai berikut :

H5 : Ketaatan Aturan Akuntansi Berpengaruh Negatif Terhadap Kecenderungan Kecurangan Akuntansi pada Karyawan Perusahaan Distributor Di Kota Bengkulu. 


\section{METODE PENELITIAN}

\section{Metode Pengambilan Sampel}

Sampel adalah bagian dari sejumlah karakteristik yang dimiliki populasi yang digunakan untuk penelitian (Sujarweni, 2014). Sampel dalam penelitian ini ditentukan dengan menggunakan teknik purposive sampling. Purposive sampling adalah teknik penetuan sampel dengan pertimbangan tertentu. Adapun sampel yang digunakan dalam penelitian ini adalah karyawan bagian keuangan atau akuntansi yang telah bekerja kurang lebih 1 tahun di perusahaan distributor tersebut.

\section{Metode Analisis Data}

Penelitian ini menggunakan metode analisis regresi linier berganda. Alat analisis yang digunakan dalam penelitian ini IBM SPSS 16.0. Hal ini dikarenakan penelitian ini adalah penelitian kuantitatif dengan satu variabel laten endogen (dependen) dan lima variabel eksogen (independen). Pemilihan metode ini sesuai dalam menganalisis data yang berasal dari kuesioner. Teknik analisis ini penting untuk memahami masalah yang terjadi.

\section{Statistik Deskriptif}

Statistik deskriptis merupakan bagian dari statistik yang mempelajari cara pengumpulan data dan penyajian data sehingga mudah dipahami. Menurut Ghozali (2011), statistik deskriptif memberikan gambaran atau deskripsi suatu data yang dilihat dari nilai rata - rata (mean), standar deviasi, varian, maksimum, minimum, sum, range, kurtosis dan skewness (kemencengan distribusi). Statistik deskriptif merupakan proses transformasi data penelitian dalam bentuk tabulasi data responden yang diperoleh dari kuesioner serta penjelasannya sehingga mudah diinterpretasikan.

\section{Uji Kualitas Data}

\section{Uji Validitas}

Uji validitas digunakan untuk mengukur sah atau valid tidaknya suatu kuesioner. Suatu kuesioner dikatakan valid jika pertanyaan pada kuesioner mampu untuk mengungkapkan sesuatu yang akan diukur oleh kuesioner tersebut. Seperti pada penelitian ini, pertanyaan dalam kuesioner yang digunakan untuk mengukur variabel kualitas sistem informasi, kualitas informasi, kualitas layanan, kepuasan pengguna dan kinerja perusahaan harus benar-benar menggambarkan dan mengungkapkan variabel tersebut (Ghozali, 2012).

\section{Uji Reliabilitas}

Uji reliabilitas adalah alat untuk mengukur suatu kuesioner yang merupakan indikator dari suatu variabel atau konstruk. Reliabilitas menunjukkan sejauh mana suatu instrumen memberikan hasil pengukuran yang konsisten apabila pengukuran dilakukan berulang-ulang. Dengan kata lain, suatu kuisioner dikatakan reliabel atau handal jika jawaban seseorang terhadap pertanyaan adalah konsisten atau stabil dari waktu ke waktu (Ghozali,2012). Kuesioner yang reliabel akan menghasilkan data yang benar atau data yang sesuai dengan kondisi sesungguhnya. Suatu variabel dikatakan reliabel atau handal apabila memberikan nilai Cronbach's Alpha $\geq 0,6$. 


\section{Uji Asumsi Klasik}

\section{Uji Normalitas}

Uji normalitas bertujuan untuk menguji apakah dalam model regresi, variabel pengganggu atau residual memiliki distribusi normal (Ghozali, 2012).Model regresi yang baik adalah yang memiliki distribusi data normal atau mendekati normal. Pada penelitian ini terdapat dua cara untuk mendeteksi apakah residual berdistribusi normal atau tidak. Uji normalitas residual dilakukan dengan menggunakan Kolmogorov-Smirnov test dengan taraf signifikan $5 \%$. Dasar pengambilan keputusan nilai Sig $\geq 0,05$ maka dikatakan berdistribusi normal. Jika nilai Sig < 0,05 maka dikatakan berdistribusi tidak normal.

\section{Uji Multikolinearitas}

Uji multikolonieritas bertujuan untuk menguji apakah model regresi ditemukan adanya korelasi antar variabel bebas (independen). Model regresi yang baik seharusnya tidak terjadi korelasi di antara variabel independen. Jika variabel independen saling berkorelasi, maka variabel-variabel ini tidak ortogonal. Variabel ortogonal adalah variabel independen yang nilai korelasi antar sesama variabel independen sama dengan nol. Uji multikolinieritas dapat dilakukan dengan 2 cara yaitu dengan melihat VIF (Variance Inflation Factors) dan nilai tolerance. Jika VIF > 10 dan nilai Tolerance < 0,10 maka terjadi gejala Multikolinieritas (Ghozali, 2011).

\section{Uji Heteroskedasitas}

Uji heteroskedastisitas bertujuan untuk menguji apakah nilai dalam model regresi terjadi ketidaksamaan varian residual satu pengamatan ke pengamatan yang lain. Jika varian dari residual satu pengamatan ke pengamatan yang lain tetap, maka disebut Homoskedastisitas dan jika berbeda disebut Heteroskedastisitas.

\section{Pengujian Hipotesis}

\section{Uji Model (Uji F)}

Uji F dilakukan untuk menguji pengaruh variabel independen secara simultan atau bersama-sama terhadap variabel dependen.Uji $F$ atau ANOVA dilakukan dengan membandingkan tingkat signifikansi yang ditetapkan untuk penelitian dengan probability value dari hasil penelitian (Ghozali, 2012). Kriteria dalam pengujian ini adalah:

1. Jika Probability value $<0,05$, maka Ha diterima.

2. Jika $p$ value $>0,05$ maka Ha ditolak.

\section{Uji Hipotesis (Uji t)}

Uji t bertujuan untuk menguji apakah variabel secara parsial atau individual terhadap variabel dependen (Ghozali, 2012). Uji t tersebut dapat dilihat dari besarnya p-value dibandingkan dengan taraf signifikasi $\alpha=5 \%$. Pengujian ini memiliki kriteria:

1. Jika $\mathrm{p}$-value $<0,05$ maka Ho ditolak.

2. Jika p-value $>0,05$ maka Ho diterima. 
PENGARUH EFEKTIVITAS PENGENDALIAN INTERNAL,...

Irwansyah dan Bambang Syufriadi

HASIL DAN PEMBAHASAN

Tingkat Pengambilan Kuesioner

Rincian Pengiriman dan Pengembalian Kuesioner

\begin{tabular}{l|c|c}
\hline \multirow{2}{*}{ Keterangan } & \multicolumn{2}{c}{ Responden } \\
\cline { 2 - 3 }- & Jumlah & Persentase \\
\hline Total Kuesioner yang disebarkan & 84 & $100 \%$ \\
\hline Jumlah Kesioner yang tidak kembali & 20 & $23,81 \%$ \\
\hline Jumlah kuesioner yang kembali & 64 & $76,19 \%$ \\
\hline Kuesioner yang tidak dapat diolah & 14 & $22,61 \%$ \\
\hline Kuesioner yang dapat diolah & 50 & $59,52 \%$ \\
\hline
\end{tabular}

Sumber: Data primer yang diolah, 2018

Uji Hipotesis

\begin{tabular}{|c|c|c|c|c|}
\hline Variabel & Koefisien & t_hitung & Sia & U \\
\hline $\begin{array}{l}\text { Efektivitas } \\
\text { Pengendalian } \\
\text { Internal }\end{array}$ & $-0,527$ & $-3,904$ & 0,000 & Diterima \\
\hline $\begin{array}{l}\text { Kesesuaian } \\
\text { Kompensasi }\end{array}$ & 0,207 & 1,788 & 0,114 & Ditolak \\
\hline $\begin{array}{l}\text { Moralitas } \\
\text { Manajemen }\end{array}$ & $-0,179$ & $-1,614$ & 0,044 & Diterima \\
\hline $\begin{array}{l}\text { Ketaatan Aturan } \\
\text { Akuntansi }\end{array}$ & $-0,271$ & $-2,440$ & 0,081 & Ditolak \\
\hline $\begin{array}{l}\text { Asimetri } \\
\text { Informasi }\end{array}$ & $-0,272$ & $-2,076$ & 0,019 & Diterima \\
\hline R Square & \multicolumn{4}{|c|}{0,485} \\
\hline Adjusted $\mathrm{R}^{2}$ & \multicolumn{4}{|c|}{0,426} \\
\hline$F$ & \multicolumn{4}{|c|}{8,275} \\
\hline Sig. & \multicolumn{4}{|c|}{0,000} \\
\hline
\end{tabular}

Sumber: Data primer diolah, 2018

\section{PEMBAHASAN}

1. Nilai probabilitas untuk variabel efektivitas pengendalian internal (H1) yaitu sebesar 0,000 berarti lebih kecil dari 0,05. Maka dapat disimpulkan bahwa Ho ditolak dan Ha diterima, artinya bahwa variabel efektivitas pengendalian internal berpengaruh negatif 
terhadap kecenderungan kecurangan akuntansi. Dengan demikian efektivitas pengendalian internal (H1) dalam penelitian ini diterima.

2. Nilai probabilitas untuk variabel kesesuaian kompensasi (H2) yaitu sebesar 0.114 berarti lebih besar dari 0,05. . Maka dapat disimpulkan bahwa Ho diterima dan Ha ditolak, artinya bahwa variabel kesesuaian kompensasi tidak berpengaruh negatif terhadap kecenderungan kecurangan akuntansi. Dengan demikian kesesuaian kompensasi (H2) dalam penelitian ini ditolak.

3. Nilai probabilitas untuk variabel moralitas manajemen (H3) sebesar 0.044 berarti lebih kecil dari 0,05. Maka dapat disimpulkan bahwa Ho ditolak dan Ha diterima, artinya bahwa variabel moralitas manajemen tidak berpengaruh negatif terhadap kecenderungan kecurangan akuntansi. Dengan demikian moralitas manajemen $(\mathrm{H} 3)$ dalam penelitian ini diterima.

4. Nilai probabilitas untuk variabel asimetri informasi (H4) sebesar 0.019 berarti lebih kecil dari 0,05. . Maka dapat disimpulkan bahwa Ho ditolak dan Ha diterima, artinya bahwa variabel asimetri informasi berpengaruh positif terhadap kecenderungan kecurangan akuntansi. Dengan demikian asimetri informasi (H4) dalam penelitian ini diterima.

5. Nilai probabilitas untuk variabel ketaatan aturan akuntansi (H5) sebesar 0.081 berarti lebih besar dari 0,05. Maka dapat disimpulkan bahwa Ho diterima dan Ha ditolak, artinya bahwa variabel ketaatan aturan akuntansi tidak berpengaruh negatif terhadap kecenderungan kecurangan akuntansi. Dengan demikian variabel ketaatan aturan akuntansi (H5) dalam penelitian ini ditolak.

\section{PENUTUP}

\section{Simpulan}

Berdasarkan hasil analisis dan pembahasan yang telah dilakukan, maka diperoleh kesimpulan sebagai berikut:

1. Efektivitas pengendalian internal berpengaruh negatif terhadap kecenderungan kecurangan akuntansi di Perusahaan Distributor Kota Bengkulu. Hal ini menunjukkan bahwa perusahaan memiliki pengendalian internal yang efektif dapat mengurangi tingkat kecenderungan kecurangan akuntansi yang dilakukan oleh karyawan.

2. Kesesuaian kompensasi tidak berpengaruh negatif terhadap kecenderungan kecurangan akuntansi yang dilakukan oleh karyawan akuntansi dan keuangan di Perusahaan Distributor Kota Bengkulu. Hal ini menunjukkan bahwa perusahaan yang memberikan kompensasi yang sesuai tidak menjamin dapat menguragi tingkat kecenderungan kecurangan akuntansi yang dilakukan oleh karyawan.

3. Moralitas manajemen tidak berpengaruh negatif terhadap kecenderungan kecurangan akuntansi yang dilakukan oleh karyawan akuntansi dan keuangan di Perusahaan Distributor Kota Bengkulu. Hal ini menunjukkan bahwa perusahaan yang memiliki moralitas manajemen yang tinggi tidak menjamin dapat menguragi tingkat kecenderungan kecurangan akuntansi yang dilakukan oleh karyawan.

4. Asimetri informasi berpengaruh positif terhadap kecenderungan kecurangan akuntansi di Perusahaan Distributor Kota Bengkulu. Hal ini menunjukkan bahwa perusahaan yang memiliki asimetri informasi yang rendah dapat menguragi tingkat kecenderungan kecurangan akuntansi yang dilakukan oleh karyawan.

5. Ketaatan aturan akuntansi berpengaruh negatif terhadap kecenderungan kecurangan akuntansi di Perusahaan Distributor Kota Bengkulu. Hal ini menunjukkan bahwa semakin taat karyawan akan aturan yang telah dibuat dapat menguragi tingkat kecenderungan kecurangan akuntansi yang dilakukan oleh karyawan. 


\section{Saran}

Berdasarkan kesimpulan dan keterbatasan yang ada, maka dapat dikemukakan beberapa saran yang dapat dijadikan pertimbangan untuk penelitian lanjutan, yaitu:

1. Peneliti selanjutnya disarankan bagi variabel yang tidak terbukti dapat tidak diuji atau diuji kembali, tetapi penelitian selanjutnya perlu mengevaluasi indikator yang ditanyakan pada kuesioner agar responden lebih mudah memahami ini dari pernyataan pada kuesioner yang peneliti berikan.

2. Penelitian selanjutnya diharapkan untuk memperbanyak jumlah sampel dengan memperluas jumlah perusahaan yang dijadikan objek penelitian agar hasil penelitiannya lebih variatif.

\section{Implikasi Penelitian}

Berdasarkan hasil penelitian dan kesimpulan diatas, maka penelitian ini memiliki implikasi sebagai berikut:

1. Secara praktis, penelitian ini dapat memberikan kontribusi bagi perusahaan bahwa hasil penelitian ini bias menjadi bahan masukkan untuk memahami apa saja faktor-faktor yang mempengaruhi kecenderungan seseorang melakukan kecurangan pada bagian akuntansi di perusahaan distributor di Kota Bengkulu, karena hasil penelitian ini menemukan bahwa pengendalian internal yang efektif, ketaatan aturan akuntansi, dan asimetri informasi dapat mengurangi kecenderungan seseorang melakukan kecurangan akuntansi. Jadi, perusahaan dapat mengetahui bahwa pengendalian internal yang diterapkan telah efektif, asimetri informasi yang terjadi di perusahaan cukup rendah, tingkat ketaatan karyawan akan aturan akuntansi cukup tinggi, sehingga dapat mengurangi kecenderungan untuk melakukan kecurangan akuntansi.

2. Secara teoritis, penelitian ini dapat menjadi pedoman, pembelajaran, dan sumbangan pemikiran bagi pengembangan Fraud Diamond Theory dan teori atribusi yang dapat mempengaruhi ialah efektivitas pengendalian internal, ketaatan aturan akuntansi, dan asimetri informasi dalam melakukan tindakan kecurangan akuntansi. Hasil penelitian ini juga dapat memperkaya referensi penelitian di bidang akuntansi khususnya akuntansi keperilakuan.

\section{Keterbatasan Penelitian}

Penelitian ini masih jauh dari kata sempurna, hal ini karena penelitian ini memiliki beberapa keterbatasan, antara lain::

1. Dalam penelitian ini hipotesis kedua dan ketiga tidak terbukti berpengaruh negatif terhadap kecenderungan kecurangan akuntansi, hal ini dikarenakan indikator dalam penelitian ini mengadopsi penelitian sebelumnya, sehingga ada beberapa indikator pada variabel tersebut sulit untuk dipahami responden.

2. Pemilihan sampel penelitian ini yaitu perusahaan distributor yang menjaga kerahasiaan, sehingga menjadikan pendistribusian kuesioner tidak dapat dimaksimalkan.

\section{DAFTAR PUSTAKA}

Aprishella, Ananda Parasmita Ayu Putri. (2014). Pengaruh Keefektifan Pengendalian Internal dan Kepuasan Kerja terhadap Kecenderungan Kecurangan Akuntansi pada Dinas Pendapatan Pengelolaan Keuangan Aset Daerah Istimewa Yogyakarta. Jurnal Nominal (Volume III Nomor 1 / Tahun 2014). Hlm. 3-4. 
Aranta, Zulia Petra. 2013. Pengaruh Moralitas Aparat dan Asimetri Informasi terhadap Kecenderungan Kecurangan Akuntansi (Studi Empiris Pemerintah Kota Sawahlunto). Jurnal Program Studi Akuntansi Universitas Negeri Padang.

Arifiyani, Hesti Arlich dan Sukirno. (2012). Pengaruh Pengendalian Intern, Kepatuhan Dan Kompensasi Manajemen Terhadap Perilaku Etis Karyawan (Studi Kasus PT Adi Satria Abadi Yogyakarta). Jurnal Nominal. Volume I Nomor I / Tahun 2012. Hlm 78.

Arens, A. Alvin. Elder, J. Ronald \& Beasley, Mark S. 2012. Auditing dan Pelayanan Verifikasi. Jakarta : Erlangga.

Boyton, William C. Raymond Johson Walter G. Kell. 2002. Modern Auditing. Erlangga: Jakarta.

Eisenhardt, Kathleem.1989. Agency Theory: An Assesment and Review. Academy of Management Review, 14. Hal 57-74. Analisis Regresi berganda dengan menggunakan software SPSS.

Fatun, Anik Najahningrum. 2013. Faktor-Faktor Yang mempengaruhi kecenderungan (Fraud): Persepsi Pegawai Dinas Provinsi DIY. Skripsi Akuntansi. Universitas Negeri Semarang.

Fauwzi, Mohammad Glifandi Hari. 2011. Analisis Pengaruh Keefektifan Pengendalian Internal, Persepsi Kesesuaian Kompensasi, Moralitas Manajemen terhadap Perilaku Tidak Etis dan Kecenderungan Kecurangan Akuntansi. Universitas Diponegoro: Semarang.

Ghozali, Imam. 2012. Aplikasi Analisis Multivariate dengan Program SPSS. Badan Penerbit Universitas Diponegoro. Semarang.

Hall, James A. 2007. Sistem Informasi Akuntansi. Edisi Ketiga. Terjemahan Oleh Amir Abadi Yusuf. Jakarta: Salemba Empat.

Herman, Lisa A. 2013. Pengaruh Keadilan Organisasi dan Sistem Pengendalian Intern Terhadap Kecurangan.Jurnal Akuntansi. Padang.

Hernandez, J. R. dan T. Groot. (2007). "Corporate Fraud: Preventive Controls Which Lower Corporate Fraud. Amsterdam Research Centre in Accounting.

Ikatan Akuntan Indonesia. 2001. Pernyataan Standar Auditing (PSA)No. 70 :Pertimbangan atas Kecurangan dalam Audit Laporan Keuangan. Jakarta: IAI.

Jensen, and W. H. Meckling, 1976. Theory of the Firm: Manegerial behavior, agency costs and ownership structure. Journal of financial Economics. vol. 3 : 305-360.

Kusumastuti. 2012. Analisis Faktor-faktor yang Berpengaruh Terhadap Kecenderungan Kecurangan Akuntansi dengan Perilaku Tidak Etis sebagai Variabel Intervening.Tesis. Universitas Diponegoro: Semarang.

Meliany, Lia \& Herna Ernawati. 2013. Pengaruh Keefektifan Pengendalian Internal dan Kesesuaian Kompensasi Terhadap Kecenderungan Kecurangan Akuntansi. Journal \& Proceeding Universitas Jenderal Soedirman, Vol III, No.1. Hal.1-10.

Najahningrum, Anik Fatun. 2013. Faktor-Faktor yang Mempengaruhi Fraud:Persepsi Pegawai Dinas Provinsi DIY. Universitas Negeri Semarang: Accounting Analysis Journal. ISSN 2252-6765.

Norbarani. 2012. Pendeteksian Kecurangan Laporan Keuangan Dengan Analisis Fraud Triangel Yang Diadopsi Dalam SAS No.99.Jurnal. Semarang.

Puspitasari, Novita dan Eko Suwardi. 2012. Pengaruh Moralitas Individu dan Pengendalian Internal Terhadap Kecenderungan Kecurangan Akuntansi: Studi Eksperimen pada Konteks Pemerintahan Daerah. Jurnal Akuntansi Universitas Gajah Mada.

Rahmawati, Ardiana Peni, 2012. Analisis Faktor Internal dan Moralitas Manajemen terhadap Kecenderungan Akuntansi. Skripsi: Universitas Diponegoro. 
Irwansyah dan Bambang Syufriadi

Republik Indonesia. (2008). Peraturan Pemerintah No. 60 Tahun 2008 tentang Sistem Pengendalian Intern. Lembaran Negara RI Tahun 2008. Sekretariat Negara. Jakarta.

Setiawan, Yuniarta. 2015. Pengaruh Sistem Pengendalian Internal, Asimetri Informasi, dan Keadilan Organisasi Terhadap Kecurangan (Fraud): Studi pada Bank Perkreditan Rakyat Se-Kabupaten Bulelang. Universitas Pendidikan Ganesha. Volume 2 No. 1 Tahun 2014. Hlm. 1-11

Shintadevi, Prekanida Farizqa. 2015. Pengaruh Keefektifan Pengendalian Internal, Ketaatan Aturan Akuntansi dan Kesesuaian Kompensasi terhadap Kecenderungan Kecurangan Akuntansi Dengan Perilaku tidak Etis Sebagai Variabel Interveining. Jurnal Nominal Vol. IV (2).

Tiara, Delfi. 2014. Pengaruh Efektifitas Pengendalian Internal dan Kesesuaian Kompensasi terhadap Kecenderungan Kecurangan Akuntansi. JOM FEKON Vol. 1 No.2.

Thoyibatun, Siti. (2009). Faktor-Faktor yang Berpengaruh terhadap Perilaku Tidak Etis dan Kecenderungan Kecurangan Akuntansi. Jurnal Ekonomi dan Keuangan Vol.26 No.2.

Tuanakotta, Theodorus. M. 2010. Akuntansi Forensik \& Audit Investigatif. Seri Departemen Akuntansi : FEUI.

Vani Adelin. 2013. Pengaruh Pengendalian Internal, Ketaatan Aturan Akuntansi, dan Perilaku Tidak Etis terhadap Kecenderungan Kecurangan Akuntansi (Studi Empiris pada BUMN di Kota Padang). Skripsi. Universitas Negeri Padang.

Wilopo. 2006. Analisis Faktor-faktor yang Berpengaruh terhadap Kecenderungan Kecurangan Akuntansi: Studi pada Perusahaan Publik dan Badan Usaha Milik Negara di Indonesia. Disampaikan dalam Simposium Nasional Akuntansi IX, Tanggal 23-26 Agustus 2006 di Padang.

Wisnumurti, Adhika. 2010. Analisis Pengaruh Corporate Governance Terhadap Hubungan Asimetri Informasi Denganm Praktik Manajemen Laba (Studi Pada Perusahaan Perbankan Yang Terdaftar di BEI). Skripsi. Fakultas Ekonomi Univeritas Diponegoro.

Yuli, Deri. 2013. Analisis Faktor-Faktor Yang Berpengaruh Terhadap Perilaku Tidak Etis Akuntansi(Studi Empiris Pada SKPD di Kota Padang). Skripsi tidak dipublikasikan, FE UNP: Padang.

Zimbelman. Mark F. 2014. Akuntansi Forensik. (Alih Bahasa: Novita Puspitasari, Suhernita, Ratna Saraswati). Jakarta: Salemba Empat. 